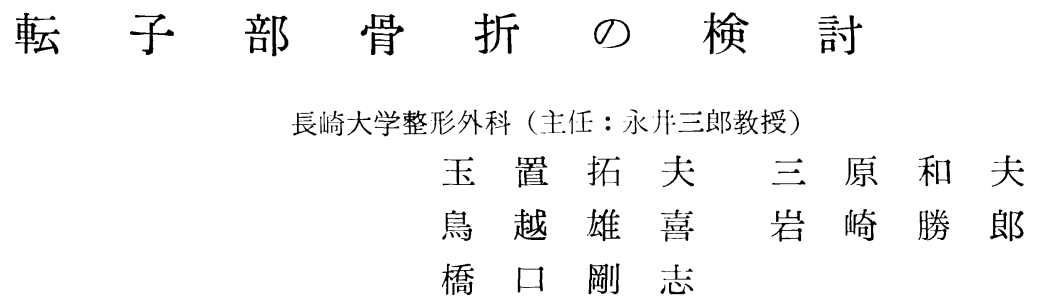

\title{
Some Observation on the Trochanteric Fractures of the Femur
}

By

\section{T. Tamaki, K. Mihara, T. Torigoshi, T. Hashiguchi and K. Iwasaki \\ Department of Orthopedic Surgery, Nagasaki University, Medical School.}

\section{まえがき}

転子部骨折は従来内側頸部骨折よりも，高年分者層 に発生することが統計的に明らかにされているが，木 邦におりる平均余价の延び，すなはち高伶者層の增加 は転子部骨折の頻度と密接な関係があると思われる。 そして, 従来この部骨折に比較的楽観的であつた理由 は多々あるが, 老人の活㲜籁囲の拡大や家族制度の崩 壊等は, 浯々に慢然たる治療法の再娭捨を装求するむ のと考えられる．㳭々は加る考虑のもとに，教室お よびその傘下病院の協力を得て集計を試みてみた．調 查結果からは, 玨々が考察しようとするための充分な 資料は得られなかつたが，元の多様性に富んだ骨折の Type やその処置についていささかの知見を得た.

\section{調 查 結 果}

表 1 の如く调查対象は 72 例である. 男 36 例, 女 36例で同率に発生している. この中, 積極的に固定術 を施行したものが 32 例, 保存的に取扱つたものが 40

\section{表 1}

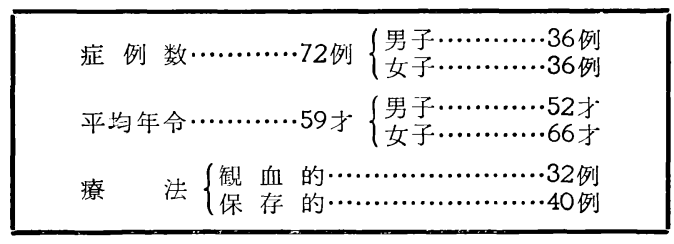

例である. 次に転子部骨折の型については, 従来種々 の分類が文献上 (Boyd, R.C. Murry, Evans) 散見 される. しかし，骨折部位による分類は治療の実際的 見地から余り意義がない，転子部骨折は極めて単純な あのから高度に複雑なものまで含まれているので，む しろ骨折部の安定性, 不安定性というところに重きを おき, さらに内固定法の選択, 予後の判定, 患者仿斻 容しうる運動や㑔荷を決定する指針ともなる Evans の分類法がより実用的である，そこで，まず Evans の分類法を簡単に紹介してみたい．まずＩ型とＩ型に わける. I 型は小転子側より外上方大転子侧に向けて 骨折線が走るもので, さらにこの部の最強の力学的構 築である頸部内側皮質に転位のないものを 1 群，又転 位はあつてあ操作により整復され得るむのを 2 群と し, 安定性を得たすのとしてての両者を安定型とす

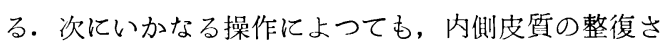
れないあのをそれぞれ 3 群，4 群とする. との両者に 内反股は必発であり，これを不安定型という．さらに 骨折線が転子下で外下方より内上方汇走るむのを II 型 とし, これも処置如何によつては大腿骨骨幹部の内方 移動は必発であり，乙れも不安定型とする．乙のよう な観点から喆々が検讨した 72 例についてみると, 表 2 の如く I 型の 3 群が最も多く $38.9 \%$ を示す. しか し, 乙の群の中には整復操作の不満足から, 安定性を 獲得し得なかつた症例むあり, この間に吾々の反省す べき余地がある．II型に属する骨折が比較的頻度の高 
表 2 骨 折 型 例 数

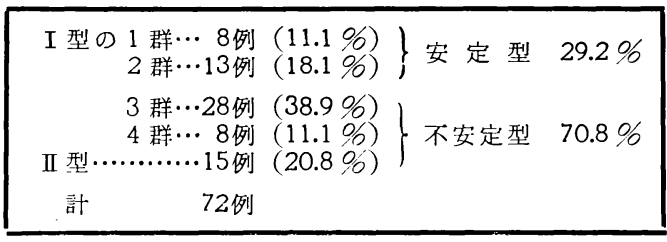

いこ上も解る.このように分類すると安定型といわれ るものが $29.2 \%$, 不安定型として变形装因を持つも のが $70.8 \%$ である. 次は観血的固定群の中で，それ ぞれの Type にいかなる固定金属材料が用いられた かを検讨してみると，I型に対して能内釗が用いられ た頻度が高い. 又 Neufeld と Mc Laughlin 釷がい かなる咼折型にも用いられていることが解る. Blade plate 耑斜位固定む少数ではあるが用いられている. 次に冒折の Type とその後の変形の起り方を検索し てみたＩ型の 1 群および 2 群の安定型に内反変帅を 残すむののないことは当然であるが, 不安定のものは
行の功緽ともいえる. そこで金属釘による固定群と保 存的治療群の内反変形の程度を検刢してみると, 次の ような表 3 になる。すなはち不安定型である 3 群, 4 群の固定例では内反変形の程度が軽度であるのに反し て, 中等度抢上び虽度の内反变形は保存的治療群のみ に汍められている. 特に 4 群の保存的治療群に変形の 虫いことは, この群の不安定性を如实に物語るもので ある.さらに第 II 型の骨折群では固定例に拉いて, 半 数以上内方転位を防止できたのに対して, 保存的治療 群ではこの内方転位が必発のむの上いえる. しかし， この内方転位は固定群であつても, その骨折の Type によつては防止できないことが解る. 次の表 4 は固定 群と保存的治療群とのベッド上の訓練開始時期および 体重負荷の時期を比較観察したすのである.ささらに, これを安定群と不安定群のものに分けて倹討した. こ の集計には種々なる予後調弪の制約があり，55症例の 平均值を求めたむのである。これによると安定型の固 定群では平均 3 週間で, ベッド上の位置移動ないし訓

表 3 骨折型とその微血的固定術执よび保存的治療法の予後（変形）

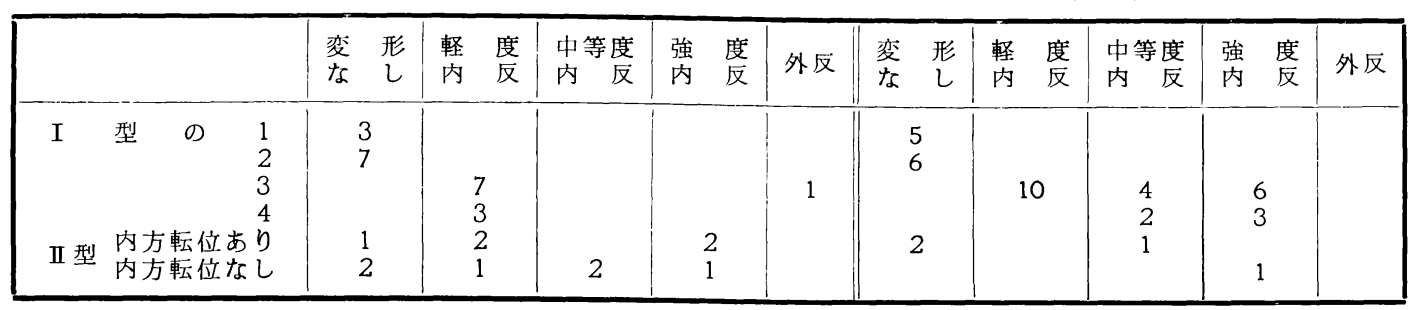

程度の差てそあれ, 内反変形は必発のものといえる. 内反股の測定はその撮影時条件がそれぞれ 異なるた め, 正碓な数值は望み得ないが, 一応軽度 $\left(115^{\circ}\right.$ ま で), 中等度 $\left(115^{\circ}\right.$ から $100^{\circ}$ まで), 強度 ( $100^{\circ}$ から $\left.80^{\circ}\right)$ のむのに分類し，特に第 II 型のむのでは大腿骨 骨幹部の内方転位のあるすのを別に抽出したＩ型の 安定型である 1 群, 2 群に内反変形のないのは当然で あろう. 不安定型であ 3 群に属するものが, 内反変非 の程度の怪いものの割合が大であることは，固定術施

表 4 運動開始括よび体重負荷時期 (55例の平均)

\begin{tabular}{|c|c|c|c|c|}
\hline & \multicolumn{2}{|c|}{ 钼血的固定群 } & \multicolumn{2}{|c|}{ 保存的治療群 } \\
\hline & 運動開始 & 体重負荷 & 運動開始 & 体重負荷 \\
\hline 安 定 群 & 3 週 & 8 週 & 5 週 & 10 週 \\
\hline 不安定群 & 4 週 & 11 週 & 13 週 & 16 週 \\
\hline
\end{tabular}

練が開始され, 体重負荷は 8 週後に許可されているの に刘し, 保存的治療例ではそれぞれ固定例よりも 2 週 間延期されていることが解る. 又, 不安定型のものの 固定群におりる運峌開始時期が 4 週であるのに対し, 保存的治療群では 13 週間の長期にわたつてベッド上 の運動訓練が開始されていない. また体重負荷が固定 群にあつては 11 週, 保存的治療群では 16 週と 1 力月 の差がある.このことから, 不安定群における体重負 荷が両者とも相当慎重であつたことがうかがえる.

\section{あとがき}

本骨折の治療法に関する論議は牽引療法を主体とす る保存療法をとるか, 種々の固定金属材料を駆使する 積極的手術療法をとるかに分かれ, その争点は解剖学 的整復, 機能的成績, 早期の位置移動, これに関連し た附木の危険度, 裤創, 全身们合併症, 死亡率等の諸点 
に倠約される. 今回の集計の結果から安定型の骨折に 対して, 解剖学的観点にかかる問題の提起はないとし ても，保存的治療群におりる早期位置移動の遷延化は 滕関節拘縮等を筆頭に老人に潜在する合併症唀発の原 因ともなり得る. 特に不安定型の本骨折に対しては早 期に固定術を行なうことが，その変形の防止に简与 し, 就中, 早期位置移㲜を谷晃にさせる意義は絶大な るあのがある.このような意味から，留々が䅡極的于 術療法を是としてみても, そこには一定の限界がある ところに問題がある. 老令と合併症が吾々に手術療法 を叶さない場合があるからである. 又術者の未熟な適 応決定と処置により, 本骨折の固定術が行なわれた絬 果は, 保存的治療例上り煩雑な事实に直面することを 銘記する必琶がある. そこにも今回吾々が調查した目 的の一つがある. すなわち頭部構築の様態が決定する 変形腤素を十分に考隹した釷の選択，ないしは釘の刺 入法がとらるべきである. たとえば不安定型の 4 群に ついて, 必発の装因をむつ内反変形に刘しては当初か ら内反位の位置で固定すべきであり，かかる考䍐をか いだ場合, 釗の Overdrive や釗の屆曲, ひいては折 損を起こす伦険も大となる，さらに型に属するもの では, 内方転位の起こることを念頭に求き, 屯し大転 子部が温存されているなら骫内釗を用いること屯有用
な手段と考えられるし，Boyd が用いた大転子部に副 子を插入するのむ一方法であろう. しかし内反変形に しても，大腿骨骨幹部の内方転位にしても，それぞれ 内反骨切り術，あるいは Mc. Murry の Osteotomy に通じるあのであり, その変帅の程度によつては，乙 机ら老人に予期される股関節症発生の予防的意義むあ るかと考える。さらに体重焦荷時期に関して屯，加 る変形装素を充分に考莣した適応決定がなされるべき である. 特に不安定型の本骨折に刘しては相当長期の 荷重制限が装求されるであろう。

最後に吾々が本骨折を調査した目的は，樍極的手術 論者のいう早期の羊動開始，早期の離床，したがつて その経済性, 快適さ, 死亡率の成少, それに反して非 手術論者のいう手術による解剖学的整復位の疑義, 適 切な管理による合併症の防止，死亡率の娍少等のする よ゙い追求に対する見解を見出す糟りのものであつた が，今回はその一部の結果を報告した次第である.

\section{文献}

1) E. M. Evans : J. B. J. S. 33-B : 2, 193.

2) H. B. Boyd: Surg. Gyn. Obst. 112:5, 633.

3) R. C. Murry: J. B. J. S. 31-B:2, 204.

4) E. M. Evans: J. B. J.S. 31-B : 2, 190. 